\title{
Małgorzata Strzelecka
}

(Toruń)

\section{Środowisko miesięcznika ,Więż" wobec reform systemu oświaty $i$ wychowania lat pięćdziesiątych i sześćdziesiątych ${ }^{*}$}

*

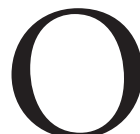

dwilż popaździernikowa stworzyła perspektywy powrotu do działalności publicystycznej środowisk katolickich oraz dla kształtowania się nowoczesnego frontu inteligencji katolickiej prezentującej podobne aspiracje i gotowość do podjęcia w nowej rzeczywistości różnych form aktywności społeczno-politycznej. Z zadowoleniem przyjęły one stwierdzenie Władysława Gomułki, iż uboga jest myśl, że socjalizm moga budować tylko komuniści, tylko ludzie o materialistycznych poglądach społecznych ${ }^{1}$. Wyrażały one także nadzieję, że podobnie, jak to się dzieje w europejskich państwach o ustroju socjalistycznym, tak również w Polsce możliwe będzie ukształtowanie nowego modelu demokracji ${ }^{2}$. W ich przekonaniu nawet $\mathrm{w}$ warunkach ograniczonej demokracji, niezależnie od odrębności ideologicznych należało

* Przygotowanie publikacji zostało sfinansowane przez Uniwersytet Mikołaja Kopernika w Toruniu w ramach grantu UMK nr 453-NH.

1 J. Woźniakowski, Kluby Inteligencji Katolickiej, „Tygodnik Powszechny”, 25 XII 1956, nr 1 , s. 7.

2 B. Bankowicz, Neopozytywizm Znaku; próba legitymizmu motywowana realizmem, [w:] B. Bankowicz, A. Dudek, Ze studiów nad dziejami Kościoła i katolicyzmu w PRL, Kraków 1996, s. 37-52; H. Słabek, Intelektualistów obraz własny 1944-1989, Warszawa 1997, s. 157-158. 
przyjmować konstruktywne i twórcze postawy społeczne $e^{3}$. Poglądy te zaowocowały integracją środowisk katolickich, która w konsekwencji doprowadziła do ukształtowania się ruchu społecznego Znak, na który składały się redakcje trzech czasopism („Tygodnika Powszechnego”, oraz miesięczników „Znak” i „Więź”), pięć Klubów Inteligencji Katolickiej (działających w Warszawie, Krakowie, Wrocławiu, Poznaniu i Toruniu) oraz Koło Poselskie „Znak”. W ruchu dominowało przekonanie, że sytuacja w Polsce będzie ewoluować w kierunku coraz większej demokratyzacji, a środowiska katolickie uzyskają szerszą możliwość wpływania na decyzje podejmowane przez różne organy władzy państwowej. Ruch ten, pozbawiony jednolitego ogólnopolskiego kierownictwa, łączyły idee doktryny katolickiej oraz niechęć do filozofii materialistycznej oraz do marksistowskiego zaplecza światopoglądowego.

O ile zamysł o konieczności zaangażowania w dokonujące przemiany wydawał się w ruchu powszechnie akceptowany, to już w zakresie sposobów podejmowanej aktywności w poglądach przedstawicieli tych ośrodków występowały poważne różnice. Skrajne wobec siebie stanowiska zajęły redakcje skupione wokół „Tygodnika Powszechnego” oraz miesięcznika „Więż”. Środowisko krakowskie, stanowiące prawicę ruchu, sformułowało program zwany neopozytywizmem, wyrażający się w praktyce zachowaniem tożsamości chrześcijańskiej oraz wyraźnego dystansu wobec koncepcji ideowych socjalizmu ${ }^{5}$. Przeciwstawne, bardziej lewicowe nastawienie przyjęła natomiast grupa katolików skupiona wokół miesięcznika „Więź”, która opowiedziała się za opcją prosocjalistyczną w sferze rozwiązań społeczno-gospodarczych.

Założycielami „Więzi” była grupa młodych działaczy i publicystów katolickich, którzy latem 1955 r. opuścili struktury „Pax-u” i na krótko pozba-

3 Zespół „Tygodnika Powszechnego”, Październik i styczeń, „Tygodnik Powszechny”, 3 II 1957, nr 5, s. 1-2; S. Stomma, W czternasta rocznice, ibidem, 20 VII 1958, nr 29, s. 1.

${ }^{4}$ A. Friszke, Opozycja polityczna w PRL 1945-1980, Londyn 1994, s. 188-189; idem, Oaza na Kopernika. Klub Inteligencji Katolickiej 1956-1989, Warszawa 1997, s. 42-54; idem, Koło Postów „Znak” w Sejmie PRL 1957-1976, Warszawa 2002, s. 5-11; P. Kazimierczak, Klub Inteligencji Katolickiej w Krakowie w latach 1956-1989, Kraków 2009, s. 9-23; M. Białkowski, Oaza na Mostowej. Klub Inteligencji Katolickiej w Toruniu 1957-2007, Toruń 2008, s. 45-69; J. Turowicz, 75xmiesięcznik „Znak”, „Tygodnik Powszechny”, 16 X 1960, nr 42, s. 3; Przemówienie Ojca Świętego z okazji 40-lecia „Znaku”, ibidem, 6 VII 1986, nr 27, s. 1 i 3; A. Biernacki, W przyszłość - nie na oślep. Srebrny jubileusz Instytutu Wydawniczego „Znak”, ibidem, 8 VII 1984, nr 28, s. 1 i 8; Czym jest Koło Poselskie „Znak?”, ibidem, 28 V 1961, nr 22, s. 1

5 S. Kisielewski, Czy neopozytywizm?, „Tygodnik Powszechny”, 25 XII 1956, nr 1, s. 4; S. Stomma, Idea i sita, ibidem, s. 5; idem, Dlaczego kandyduje do Sejmu, ibidem, 20 I 1957, nr 3, s. 2; idem, Pozytywizm od strony moralnej, ibidem, 14 IV 1957, nr 15, s. 1. 
wieni zostali możliwości wyrażania swych poglądów ${ }^{6}$. Ich sytuacja zmieniła się, gdy wspólnie z wracającymi do życia publicznego działaczami i intelektualistami katolickimi z Krakowa, Lublina i Warszawy zostali współzałożycielami Ogólnopolskiego Klubu Postępowej Inteligencji Katolickiej oraz współautorami opublikowanego na łamach „Życia Warszawy” Oświadczenia pisarzy i działaczy katolickich ${ }^{7}$. Włączyli się oni wówczas w nurt działalności Klubu Inteligencji Katolickiej w Warszawie, w którym już od jesieni 1957 r. zauważyć można było formowanie się grupy wokół Tadeusza Mazowieckiego i Janusza Zabłockiego. W lutym 1958 r. uzyskali możliwość wydawania miesięcznika „Więź”, którego redaktorem naczelnym został Tadeusz Mazowiecki.

W pierwszym numerze pisma w artykule pt. Rozdroża i wartości zespół redakcyjny przedstawił programową deklarację ideową ${ }^{8}$. O swojej otwartej i poszukującej postawie wobec współczesności napisali:

Chcemy szukać [...]. Jesteśmy ludźmi mocno wrośniętymi w glebę swej epoki. Należymy do tych, których współczesność pociąga i którym współczesność ciąży zarazem. [...] Generacja [nasza] złożona [jest] właściwie z szeregu roczników, o dużej rozpiętości, ujęta jako pokolenie ludzi, których świadomość ukształtowała się w sposób decydujący w ostatnich latach wojny i w okresie bezpośrednio powojennym - ta generacja nosi w sobie może najgłębiej dramat czasu, który z jednej strony otwiera człowiekowi niespodziewane możliwości, z drugiej zaś strony każe mu nieść ciężar nieraz nazbyt wielki do podźwignięcia?.

${ }^{6}$ AAN, Urząd do spraw Wyznań, sygn. 129/6, k. 97; zob. także: A. Dudek, G. Pytel, Bolestaw Piasecki. Próba biografii politycznej, Londyn 1990, s. 218-221; M. Rostworowski, Stowo o PAXIE 1945-1956, Warszawa 1968, s. 97-99; A. Micewski, Wspótrządzić czy nie kłamać. PAX i Znak w Polsce 1945-1976, Paryż 1978, s. 38-39.

7 J. Żakowski, Trzy ćwiartki wieku. Rozmowy z Jerzym Turowiczem, Kraków 1990, s. 99.

8 Zespół „Więzi”, Rozdroża i wartości, „Więź”, 1958, nr 2 (1), s. 5-13. Rozwinięcie założeń ideowych środowiska opublikowano w lutym 1960 r. w artykule pt. O prąd społecznego zaangażowania, w którym napisano m.in.: „Spełnienie powszechnych nadziei na to, że poprawa życia nastąpi i będzie trwała, przynieść może w naszym przekonaniu tylko postęp w socjalistycznym rozwoju społeczno-gospodarczym Polski. Jest to jedyna droga do trwałej poprawy naszego losu zbiorowego, a w konsekwencji i indywidualnego. Innej drogi nie ma” (s. 7). Wywołał on burzliwą dyskusję ideową w środowisku „Znak”, zob.: AAN, Urząd do spraw Wyznań, sygn. 129/6, k. 89, k. 105; J. Zabłocki, Dzienniki 1956-1965, t. 1, Warszawa 2008, s. 247-248.

\footnotetext{
9 Zespół „Więzi”, Rozdroża i wartości, s. 5.
} 


\section{W innym fragmencie dodawali:}

Chodzi więc o to, aby mieć aktywny, a nie pasywny stosunek do życia i nie schodzić nigdy poniżej ambicji, by na dostępnym sobie odcinku kształtować otaczającą nas rzeczywistość tak w świecie rzeczy, jak i w świecie ludzi. Jest to rola, do której każdy człowiek jest powołany, i którą odgrywać ma on nie w sferze marzeń i złudzeń, ale w konkretnych warunkach swego czasu $^{10}$. [...] Stwierdzenie, że chcemy szukać, oznacza więc na tym tle coś więcej niż tylko postawę poznawczą. [...] Chcemy najpierw wyrazić poprzez to nasz zamiar uczynienia z „Więzi” wspólnego warsztatu, w którym zarówno piszący, jak i czytający od nowa spoglądają na problemy naszej współczesności. Chcemy więc nadać naszym pracom i naszemu współdziałaniu z Czytelnikiem [...] charakter poszukiwań, weryfikacji, eksperymentatorstwa. Tak, aby - nie pretendując do nieomylności - jak najlepiej dokopywać się prawdy w każdej konkretnej sprawie i sytuacji, biorąc pod uwagę wszystkie jej złożone elementy i okoliczności ${ }^{11}$.

W kontekście tych deklaracji warto zauważyć brak podtytułu miesięcznika „Więź” informującego, że jest to pismo katolickie. Zespół redakcyjny składający z katolików podjął decyzję, by nie definiować się jako pismo katolickie, a wzorem czasopisma „Esprit” przyjąć formułę otwartą i skierowaną do wszystkich, którzy będą chcieli na jego łamach prezentować swoje poglą$\mathrm{dy}^{12}$. Na brak podtytułu niewątpliwy wpływ miał również fakt, że, nie chcąc wykorzystywać autorytetu Kościoła, podejmowali oni działalność w łączności z hierarchią kościelną, ale na własną odpowiedzialność ${ }^{13}$.

W dyskusji założycieli „Więzi” T. Mazowiecki, wspominając po latach okres kształtowania się zespołu, przypominał:

Byliśmy wtedy w trudnej sytuacji, nie mogliśmy dostać pracy, chcieliśmy założyć własne pismo. [...] Myślę więc, że najpierw powstało środowisko wyraźnie odczuwające potrzebę mówienia własnym głosem. Ideą, która nas łączyła był niewątpliwie personalizm, w którym ogniskował się fi-

${ }^{10}$ Ibidem, s. 7.

11 Ibidem, s. 6.

12 T. Mazowiecki, Pozycje i praca środowiska „Więż”, „Więź” 1961, nr 3 (35), s. 8-10; A. Krasiński, 25-lecie „Esprit”, ibidem 1958, nr 2, s. 78-84; J. Zabłocki, op. cit., s. 130.

13 T. Mazowiecki, Pozycje i praca środowiska „Więź”, s. 10-11. 
lozoficzny sprzeciw wobec totalitaryzmu - uznanie osoby ludzkiej za cel, a nie instrument, narzędzie działań. Wychodziliśmy przecież z czasów, kiedy człowiek traktowany był wyłącznie jako narzędzie polityki. Ale równocześnie był to personalizm wspólnotowy, który wydawał nam się wówczas odpowiedzią na wyzwanie czasów ${ }^{14}$.

Wojciech Wieczorek, długoletni sekretarz redakcji, a w latach 1981-1989 zastępca redaktora naczelnego, w uzupełnieniu tej wypowiedzi wyjaśnił stosunek zespołu do awangardowej wówczas katolickiej myśli francuskiej. W poglądach Emmanuela Mouniera, który należał do ludzi akceptujących komunistyczną rzeczywistość,

dla nas najistotniejsze było wówczas jego twierdzenie, że osoba ludzka to istota przerastająca historię i że, wobec tego, kategorie czysto historyczne czy też czysto socjologiczne nie wystarczą do wyjaśnienia świata i człowieka. Chodziło nam więc nie tyle o lewicowość Mouniera, co o jego personalizm. To był dla nas niezwykle istotny punkt odniesienia wobec wszechobecnej, agresywnej indoktrynacji przez ideologię marksistowską. Bardzo ważny był dla nas także Jacques Maritain i jego rozróżnienie pomiędzy sacrum i profanum. To nas uodparniało zarówno na klasyczny katolicki integryzm, jak i na próbę budowania „czerwonego” integryzmu, którą podjął Bolesław Piasecki ${ }^{15}$.

Grupa publicystów skupiona wokół miesięcznika „Wieź”, obok personalizmu, do wartości nadrzędnych zaliczała wierność zasadom Kościoła, udział we wspólnocie katolickiej oraz ideę zaangażowania społecznego katolików. Uważali oni, że katolicyzm w Polsce z powodu postępującej laicyzacji stanął wobec najtrudniejszego momentu w swoim rozwoju historycznym ${ }^{16}$. Za niezbędne uznawali wprowadzanie w Polsce socjalistycznych reform po-

14 "Więziowe pokolenia, „więziowe” oblicza”. Dyskutują założyciele „Więzi”: Tadeusz Mazowiecki i Wojciech Wieczorek oraz dzisiejszy zespót redakcyjny, „Więź”, 1998, nr 2, s. 139-140; zob. także: T. Mazowiecki, Dlaczego personalizm?, ibidem, 1958, nr 3, s. 11-23; idem, Personalizm i skutery, ibidem, 1960, nr 7-8, s. 7-13; E. Mounier, Personalistyczne zaangażowanie, ibidem, 1959, nr 5, s. 5-11.

15 „Więziowe pokolenia, „więziowe” oblicza”, s. 140; zob. A. Krasiński, Mounierowskie odkrycie historii, „Więż”, 1960, nr 3, s. 5-15.

16 T. Mazowiecki, Pozycje i praca środowiska „Więż”, s. 11. 
litycznych oraz społeczno-ekonomicznych. Swoją postawę uzasadniali następująco:

Chodzi natomiast o to, aby socjalistyczna formacja społeczno-ekonomiczna, w jaką Polska w wyniku dokonanych reform społecznych weszła, rozwijała się w kierunku najkorzystniejszym dla życia narodu i praw człowieka, którym winna ona służyć ${ }^{17}$.

\section{T. Mazowiecki w 1961 r. wyjaśniał:}

Nasza postawa wobec rzeczywistości socjalistycznej w Polsce wynika z wewnętrznego zaangażowania w taki jej rozwój, który by w coraz większym stopniu stwarzał społeczną perspektywę dla wartości osobowych. Polska w wyniku przemian strukturalnych wkroczyła na drogę szerokiego przemysłowego rozwoju. [...] Dla naszego stosunku do tych przemian, do socjalistycznej struktury społecznej istotne jest właśnie to, że w przebudowie społecznej, którą ona przyniosła, widzimy szansę dla narodowego i osobowego rozwoju. Zajmując takie stanowisko, angażując się w rozwój socjalistycznej struktury społeczno-gospodarczej w Polsce, czynimy to z własnych, personalistycznych pozycji ideowych. $Z$ tych właśnie pozycji wychodząc, stawiamy na pluralizm i ograniczony rozwój życia społecznego w ramach socjalizmu ${ }^{18}$.

Wyjaśniał, że zespół ludzi skupionych wokół „Więzi” proces umacniania pluralizmu w ustroju socjalistycznym rozumie odmiennie niż to zostało ujęte w koncepcjach tzw. politycznego katolicyzmu czy dwuświatopoglądowości. W jego przekonaniu nie można było mieszać płaszczyzny religijnej z polityczną, gdyż nie sprzyjało to budowie pluralistycznego ładu, a wręcz przeciwnie groziło tworzeniu podziałów naruszających jedność społeczną oraz zamykaniem społeczności katolickiej w izolacji i wyobcowaniem jej z życia całej społeczności, w konsekwencji pozbawieniem możliwości szerszego oddziaływania. Aby pluralizm zakorzenił się w rzeczywistości socjalistycznej jako jej element integralny, musiał on w ocenie redaktora naczelnego wynikać z naturalnego prawa osoby ludzkiej, a nie z nadania czy przydziału politycznego.

17 Zespół „Więzi”, Rozdroża i wartości, s. 12.

18 T. Mazowiecki, Pozycje i praca środowiska „Więż”, s. 12. 
Formułujące się środowisko „Więzi”, dostrzegając ujawniony podczas XX Zjazdu KPZR krach biurokratycznej koncepcji społeczeństwa, opowiadało się za ograniczonym rozwojem życia społecznego opartym na kształtowaniu różnorodnych więzi, dzięki którym człowiek mógłby znaleźć możliwości dla szerszej działalności na rzecz społeczeństwa ${ }^{19}$. Widziało ono potrzebę przekroczenia w myśleniu oraz postawie społecznej pewnego progu myślenia. T. Mazowiecki stwierdzał bowiem, że nie można byto [...] zabiegać o humanistyczna perspektywe świata socjalistycznego zachowując wobec niego wewnętrznie totalna obcośc $c^{20}$.

Zespół redakcyjny, dostrzegając błędy we wprowadzaniu socjalizmu, podjął świadome ryzyko zaangażowania się w tworzenie socjalistycznych struktur społeczno-gospodarczych, mając nadzieję na współpracę z obozem władzy w zakresie formułowania podstawowych treści społecznych socjalizmu oraz na wypracowanie przesłanek wyjściowych dla personalizacji tworzonych struktur społecznych ${ }^{21}$. Idea zaangażowania w opiniach twórców środowiska wynikała bowiem nie z pobudek doktrynalnych, lecz z chęci uczestnictwa w procesie przeobrażeń społecznych. Przy czym od początku swej działalności publicyści zastrzegali sobie równocześnie prawo do każdorazowej oceny metod i form realizacji różnych zadań socjalizmu według własnych kryteriów.

W pierwszych latach działalności pisma władze liczyły, że „Więź” jako środowisko ideowe zwiększy swój wpływ na pracę i rozwój ruchu Znak, w szczególności na KIK w Warszawie oraz na inne kluby, a nawet Katolicki Uniwersytet Lubelski ${ }^{22}$. Wyrażały także nadzieję, że podejmie ona działalność na rzecz zmniejszenia rozpiętości postaw katolików wobec idei katolicyzmu „otwartego"23. Z notatek służbowych powstałych na potrzeby Urzędu do Spraw Wyznań wynika, że w grupie skupionej wokół „Więzi” władze widzieć chciały sojusznika partii w realizacji zadań dotyczących stosunków między socjalistycznym państwem a ludźmi wierzącymi ${ }^{24}$. Rozważano możliwość podjęcia próby „przeniesienia” działalności „Więzi” z obszarów znajdujących się pod bezpośrednim oddziaływaniem państwa (wyższych uczelni, inteligencji, nauczycieli) na tereny dominujących wpływów Kościoła, szcze-

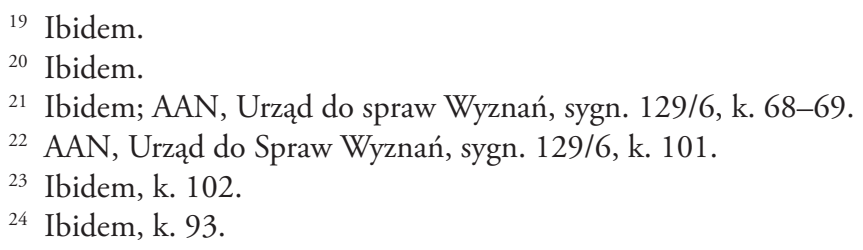


gólnie na odcinki młodzieżowe i inteligenckie, gdzie mogłaby ona występować w roli konkurencji wobec Kościoła w ideologicznym wychowaniu młodego pokolenia ${ }^{25}$.

W rzeczywistości po deklaracjach ideowych z 1958 i 1960 r., które miały zapewnić zespołowi możliwość realizacji swoich młodzieńczych lewicowych ideałów ${ }^{26}$ oraz podjęcie działalności publicystycznej, już na przełomie 1959/1960 r. w dokumentach Urzędu do spraw Wyznań odnotowano krytyczne oceny działalności tego środowiska. Podkreślano, że od czasu swojej prosocjalistycznej deklaracji z lutego 1960 r. zespół „Więzi” nie uczynił nic w kierunku jej praktycznej realizacji ${ }^{27}$. Wbrew oczekiwaniom Zespót nie potrafit się "zaangażować" i włączyć w nurt życia Kościoła ${ }^{28}$. W ingerencjach Głównego Urzędu Kontroli Prasy Publikacji i Widowisk akcentowano zauważalny w publicystyce „Więzi” przerost akcentowania negatywnych aspektów współczesności, a zbyt lakoniczne traktowanie pozytywnych osiągnięć, nieuwzględnianie okoliczności analizowanych zjawisk oraz brak włączenia się w realizację zadań „Wielkiej Nowenny”29. Systematycznie wzrastająca liczba ingerencji cenzorskich na łamach miesięcznika świadczyć mogła o tym, że zespół redakcyjny nie spełniał pokładanych w nim oczekiwań władz ${ }^{30}$. $\mathrm{Z}$ biegiem czasu nigdy nierozwinięte deklaracje prosocjalistyczne środowiska zastąpione zostały propozycjami naprawy ustroju, propagowaniem haseł demokratyzacji, liberalizacji oraz humanizacji życia społecznego ${ }^{31}$. Analiza publicystyki wskazuje, że ludzie skupieni wokół redakcji „Więzi” od początku istnienia miesięcznika w swojej publicystyce wychodzili daleko poza obszary zagadnień związanych z katolicyzmem. Proces ten narastał po 1968 r., kiedy wokół redakcji zaczęli skupiać sie ludzie pozostający w opozycji do marksizmu. W jednej z notatek oceniających publicystykę „Więzi” napisano:

Od tego momentu [od 1968 r.] coraz szerzej na łamach „Więzi” występują tendencje rewizjonistyczne zarówno w odniesieniu do historii, jak

${ }^{25}$ Chodziło przede wszystkim o środowiska: KUL, seminariów duchowych oraz młodych wikarych, zob.: ibidem, k. 94.

${ }^{26}$ Rozmowa z Wojciechem Wieczorkiem przeprowadzona 4 XI 2010 r.

27 AAN, Urząd do Spraw Wyznań, sygn. 144/11, k. 14, 30.

${ }^{28}$ Ibidem, k. 56.

${ }^{29}$ Ibidem, k. 55-56.

30 Ibidem, sygn. 144/11, k.14.

31 Ibidem, sygn. 127/187, k. 71. 
i obecnej rzeczywistości. [...] Jest to tym niebezpieczniejsze, że „Więź” jest najbardziej z pism „Znaku” wychylona ku młodym i dzięki swojej inteligentnie i perfidnie (czasem demagogicznie) robionej opozycyjności oraz głoszeniu haseł demokratycznych i liberalnych atrakcyjna ${ }^{32}$.

Proces przechodzenia pisma na pozycje opozycyjne nasilił się w latach kolejnych, szczególnie po 1976 i 1981 r., o czym świadczyła m.in. wzrastająca ilość materiałów zdjętych przez GUKPPiW ${ }^{33}$. W notatce służbowej Urzędu do spraw Wyznań zapisano: Rozmowy z redakcją prowadzone przez GUKPPiW sa bardzo trudne. Szczególnie redaktor naczelny jest agresywny, akcentujący niemożność osiagnięcia porozumienia ${ }^{34}$.

Obok problematyki religijnej, społeczno-kulturalnej i historycznej niewątpliwie do najistotniejszych obszarów zainteresowania redakcji „Więzi” należała długofalowa praca intelektualna i wychowawcza nad kształtowaniem formacji współczesnych katolików ${ }^{35}$. Publicyści, odwołując się do dorobku myśli katolickiej oraz do idei chrześcijańskiego personalizmu, wychowaniu przypisywali decydującą rolę w procesie kształtowania postaw obywateli oraz ładu społecznego. Wiązało się to z przekonaniem, że jedynie poprzez wychowanie odwołujące się do wartości religijnych możliwa będzie budowa harmonijnego oraz nienaruszającego godności i podmiotowości ludzkiej porządku społecznego. W tym procesie za niezbędną uznawali współpracę wszystkich tradycyjnych środowisk i instytucji wychowawczych.

$\mathrm{Z}$ powyższych przesłanek wynikało zainteresowanie problematyką oświatowo-wychowawczą nie tylko redakcji „Więzi”, ale całego ruchu $\mathrm{Znak}^{36}$. Środowiska katolickie z uwagą przyjęły sformułowaną na przełomie 1956/1957 r. gotowość władz oświatowych do przeprowadzenia głębokich reform, ale, jak pokazały wydarzenia następnych lat, wynikała ona raczej ze względów taktycznych niż z chęci dokonania poważnych przekształceń. Kolejną zapowiedź wprowadzenia gruntownych zmian ogłoszono na przełomie 1958/1959 r. podczas XII Plenum KC PZPR w listopadzie 1958 r.,

32 Ibidem, sygn. 127/187, k. 93.

33 Ibidem, sygn. 130/2, k. 76-77; 127/187, k. 70-75.

34 Ibidem, sygn. 127/187, k. 96.

35 T. Mazowiecki, Pozycje i praca środowiska „Więż”, s. 8-20.

36 Zob.: M. Strzelecka, Trudne kompromisy. Srodowisko "Tygodnika Powszechnego” wobec reform systemu oświaty i wychowania w latach 1945-1989, Toruń 2009. 
a potwierdzono w marcu 1959 r. w trakcie III Zjazdu PZPR ${ }^{37}$. Kierunki reform nakreślono jednak dopiero w styczniu 1961 r. podczas VII Plenum KC PZPR, w sytuacji polityczno-społecznej odbiegającej od tej, jaka istniała na przełomie 1956/1957 r. Najważniejsze decyzje dotyczyły wydłużenia o jeden rok nauki w powszechnej szkole podstawowej, nałożenia nowych zadań na licea ogólnokształcące oraz rozbudowy szkolnictwa zawodowego. Powołanie do życia 8-letniej szkoły podstawowej przyczynić się miało do rozwiązania nabrzmiałych jej problemów, które dotyczyły głównie przeładowanych programów nauczania i lepszego przygotowania młodzieży do nauki w szkole średniej. W konsekwencji miało nastąpić wydłużenie okresu nauki, która w minimalnym zakresie trwać miała 10 lat (8 lat w szkole podstawowej i co najmniej 2 lata w szkołach przyzakładowych, międzyzakładowych lub przysposobienia rolniczego). Lepszemu kształceniu młodzieży służyć miało zróżnicowanie programowe liceów ogólnokształcących. Poważnym wyzwaniem była zapowiedź rozbudowy szkolnictwa zawodowego, planowano bowiem, że w przyszłości około 70\% absolwentów szkół podstawowych będzie kontynuować naukę w szkolnictwie zawodowym ${ }^{38}$.

W uchwale VII Plenum wskazywano również na konieczność dostosowania treści nauczania do aktualnych potrzeb społecznych. W praktyce oznaczać to miało redukcję materiału humanistycznego i wyeksponowanie zagadnień z historii współczesnej oraz wprowadzenie do szkoły elementów kształcenia politechnicznego. W uchwale zalecano także zwiększenie wymiaru godzin nauczania przedmiotów ścisłych w szkole podstawowej. W przypadku przedmiotów matematycznych zmiany oznaczać miały, w porównaniu do roku 1960/1961, wzrost liczby godzin z 41\% do 46\%, w zakresie przedmiotów humanistycznych zmniejszenie z 41\% do 38\%, a w przypadku przedmiotów artystycznych i wychowania fizycznego redukcję z $18 \%$ do $16 \%{ }^{39}$. Założenia reformy stawiały przed władzami oświatowymi trudne zadania szczególnie w zakresie przygotowania odpowiednio wykwalifikowanych kadr nauczycieli. Szacowano, iż wobec nadchodzącego wyżu demograficznego do pracy z młodzieżą na najbliższe 10 lat potrzeba będzie około 120 tysięcy nowych nauczycieli ${ }^{40}$.

37 W. Ozga, Organizacja szkolnictwa w Polsce, Warszawa 1960, s. 152-153.

38 Ibidem.

39 Ibidem, s. 153-155.

40 K. Trzebiatowski, Organizacja i podstawy prawne szkolnictwa, Gdańsk 1968, s. 164-188. 
Ustawę o rozwoju systemu oświaty i wychowania przygotował resort oświaty pod kierunkiem ministra Wacława Tułodzieckiego ${ }^{41}$. Przyjęta ona została po dwudniowej debacie sejmowej w dniu 15 lipca $1961 \mathrm{r}$. Z uwagi na wiele kontrowersyjnych postanowień członkowie Koła Poselskiego „Znak” nie udzielili jej swojego poparcia. Projekt został przegłosowany przy pięciu głosach wstrzymujących się Konstantego Łubieńskiego, Stefana Kisielewskiego, Tadeusza Mazowieckiego, Stanisława Stommy oraz Jerzego Zawieyskiego ${ }^{42}$.

Problematykę związaną z procesem kształcenia i wychowania nowych pokoleń Polaków na łamach „Więzi” podejmowano wielokrotnie. Artykułom eksponującym analizę zagadnień oświatowo-wychowawczych towarzyszyły badania ankietowe, w których podejmowano próby określenia stosunku młodzieży do wartości przekazywanych przez pokolenie starsze czy też losów absolwentów szkół wyższych z lat 1956-196043. Publicyści warszawskiego miesięcznika, dostrzegając nabrzmiałe problemy systemu edukacji, wyrażali niezadowolenie z braku dyskusji oraz z zaniechania prób uświadamiania społeczeństwa w tych niezmiernie ważnych zagadnieniach, które ginęły w natłoku innych pilnych spraw i były odsuwane na bliżej nieokreślony termin realizacji ${ }^{44}$. Zauważali, że

opinia publiczna nadal bardzo niewiele wie o ogromnej złożoności spraw oświaty w Polsce i o skali trudności, jakie tu stoją do pokonania. [...] Od kilku lat nie mamy wyczerpujących informacji i polemik nad aspektem ekonomiczno-finansowym reformy, brak wiadomości o socjologicznych analizach proponowanych wariantów, nikły oddźwięk wywołują głosy o nowych metodach w pedagogice, niewiele wiemy o koncepcjach

41 Ustawa z dnia 15 lipca 1961 roku o rozwoju systemu oświaty i wychowania, DzU 1961, nr 32, poz. 160; A. Friszke, Koło Postów „Znak” w Sejmie 1957-1976, Warszawa 2002, s. 46-47; M. Łętowski, Ruch i Koło Poselskie Znak, Katowice 1998, s. 158.

42 Gtównie o reformie szkolnictwa, „Tygodnik Powszechny”, 30 VII 1961, nr 31, s. 2.

43 J. Zabłocki, Nad ankieta „Więzi”, „Więź” 1959, nr 5, s. 22-35; Konkurs dla absolwentów szkót wyższych z lat 1956-1960, „Więż” 1961, nr 7-8, s. 7-10; zob. także: T. Żółciński, Humaniści boją się prowincji, „Więź”, 1961, nr 1, s. 95-107; W. Kalkowski, Młodzież wiejska w oczach duszpasterza, „Więz”” 1961, nr 4, s. 41-52; J. Dunin, Zawodowi humaniści i ich kompleksy, „Więź” 1961, nr 11-12, s. 149-155; J. Starnawski, Literatura polska w wypisach szkolnych, „Więż”, 1963, nr 5, s. 81-92.

${ }^{4}$ J. Wejroch, A. Wielowieyski, Kryzys i reforma systemu oświaty, „Więż”, 1962, nr 5, s. 5. 
rozwoju szkolnictwa zawodowego, o dialektyce prac nad programami, o następnych etapach reformy, itp. ${ }^{45}$

W debacie sejmowej nad ustawą o rozwoju systemu oświaty, przemawiający po raz pierwszy z trybuny sejmowej, T. Mazowiecki wskazał na konieczność głębokich zmian ${ }^{46}$. Podkreślił on sukcesy polityki państwa w dziedzinie upowszechnienia oświaty, akcentując wzrost liczby uczniów kończących szkoły podstawowe (z 25\% do 87\%), ponaddwukrotne zwiększenie liczby absolwentów liceów ogólnokształcących, trzykrotne powiększenie liczby uczniów wszelkiego typu szkół zawodowych, częściową likwidację przepaści między przebiegiem edukacji na wsi i w mieście, rozwój różnego rodzaju placówek oświatowych oraz wydłużenie kształcenia poprzez sieć placówek edukacyjnych dla dorosłych. Za właściwe uznał zmiany idące w kierunku wydłużenia czasu nauki młodzieży oraz zbliżenia szkoły z pracą zawodową, rozumianą jako przyszłą dziedzinę aktywności absolwenta.

Praktyczna realizacja zapowiadanych reform w jego przekonaniu wymagać miała jednak od władz oświatowych wykonania dalszych studiów, eksperymentów oraz zorganizowania i skoordynowania współpracy różnych kręgów specjalistów, dydaktyków, nauczycieli praktyków, psychologów, pedagogów oraz pracowników naukowych. Zaproponowany kierunek reform w jego zdaniem zakończyć się miał sukcesem tylko wtedy, gdy realizacja zakładanych zmian odbywać się będzie w wariancie ambitnym, nie sprowadzającym nauki szkolnej jedynie do sfery praktycznego wymiaru. Szkoła bowiem realizować powinna w sposób harmonijny swoje zadania, tak z zakresu kształcenia ogólnego, jak i specjalistycznego. Należało zatem

rozbudzić umiejętność samodzielnego myślenia i posługiwania się zdobytą wiedzą. Przysposabiając do pracy zawodowej szkoła ma dawać podstawy teoretyczne i umiejętności praktyczne, pozwalające na orientowanie się w postępie wiedzy i na nieustanne dopełnianie swych umiejętności ${ }^{47}$.

45 Ibidem; A. Friszke, Koto Postów „Znak” w Sejmie 1957-1976, s. 46-47.

46 Sprawozdanie stenograficzne z 3 posiedzenia Sejmu PRL w dniu 14 i 15 lipca 1961 r., sesja I, Warszawa 1961, 1. 84-91; T. Mazowiecki, Przemówienie sejmowe, „Tygodnik Powszechny”, 30 VII 1961, nr 31, s. 2 i 4.

47 T. Mazowiecki, Przemówienie sejmowe, s. 2. 
Nieprzemyślana rezygnacja z nauczania teoretycznego w jego przekonaniu mogła zachwiać podstawowe funkcje szkoły w zakresie przekazywania podstaw kultury ogólnej, jak i wychowania obywatelskiego. Nowe zadania szkoły średniej powinny wyrażać się w komplementarnym traktowaniu nauki nowoczesnego przysposobienia zawodowego oraz przygotowywaniu młodzieży do uczestnictwa w życiu społecznym i kulturalnym kraju. Kierunek zaproponowanych zmian wymagał poważnego przepracowania metod pracy, zakresu nauczania oraz utrzymania właściwych proporcji między nauczaniem ogólnym i praktycznym ${ }^{48}$.

Zastrzeżenie o fundamentalnym dla środowiska Znaku znaczeniu wzbudzał artykuł 1 ustawy, który do perspektywicznych celów szkoły zaliczył na pierwszym miejscu kształtowanie naukowego poglądu na świat. Założenie to było niemożliwe do zaakceptowania przez katolików, gdyż nie respektowało wyznawanego przez nich systemu wartości oraz nie odpowiadało wymogom społeczeństwa pluralistycznego. Ważnym sygnałem określającym stanowisko władz wobec tych zastrzeżeń było odrzucenie kompromisowej poprawki zgłoszonej przez przedstawicieli Klubu Poselskiego „Znak” do Komisji Oświaty i Kultury, w której zaproponowano zastąpienie spornego fragmentu ustawy formułą wskazującą, że zadaniem szkoły będzie kształtowanie postawy i poglądów opartych o wiedzę naukową.

Tadeusz Mazowiecki, prezentując na forum parlamentu opinie katolików, wykazywał zrozumienie dla istnienia w zróżnicowanym światopoglądowo społeczeństwie jednolitego i świeckiego szkolnictwa państwowego ${ }^{49}$. Podkreślał jednak, że zasadzie świeckości szkoły można przypisywać różną treść. Szkoła jako placówka oświatowo-wychowawcza winna stwarzać warunki dla takiego funkcjonowania instytucji społecznych, w których możliwy byłby swobodny wybór, a nie narzucanie i faworyzowanie jednego światopoglądu. Zasada świeckości powinna sprzyjać klimatowi zgodnego współżycia ludzi posiadających różne poglądy na świat. Jednoznacznie podkreślił także, że szkoła, realizując powszechny obowiązek nauki, z której korzystają na równych zasadach ludzie wierzący i niewierzący, nie może stawiać za ustawowy cel wychowawczy problemu ujednolicenia światopoglądowego. Wychowując ideowych, a przede wszystkim myślących obywateli powinna ona kształtować zespół wspólnych wartości oraz wpajać szacunek i zrozumienie dla

\footnotetext{
48 Ibidem.

49 Sprawozdanie stenograficzne z 3 posiedzenia..., 1. 87-88.
} 
różnych poglądów. Przedstawiając odmienną od zaproponowanej w ustawie wizję szkoły przyszłości podkreślał, że katolickiemu środowisku nie chodzi o szkołę neutralną i nijaką wychowawczo. Chodziło raczej o szkołę wychowującą do życia we współczesnym, zróżnicowanym światopoglądowo społeczeństwie, koncentrującą swoje funkcje wychowawcze na wartościach wspólnych społeczeństwu socjalistycznemu, lojalnie informującą o tym, co jest w interpretacji nauki sporne i dyskusyjne, szkołę, w której odmienność światopoglądowa nie byłaby czynnikiem deprecjonującym. W swym wystąpieniu wskazywał również na konieczność uregulowania problemu nauczania religii poza szkołą ${ }^{50}$. Z uznaniem przyją fakt, iż ustawa przewidywała możliwość udzielania przez Ministerstwo Oświaty zezwoleń na prowadzenie szkół przez instytucje społeczne, w tym wyznaniowe.

Zasadna wydaje się w tym miejscu konstatacja, iż zasadnicze założenia przyjętej 15 lipca $1961 \mathrm{r}$. ustawy nawiązywały do programu wysuniętego na zjeździe oświatowym w Łodzi w 1945 r., który wówczas nie mógł zostać zrealizowany z uwagi na trudności kadrowe i lokalowe państwa. Nowy aspektem wprowadzanego prawa oświatowego była natomiast laicyzacja szkół i placówek wychowawczych. W praktyce oznaczała ona likwidację dualizmu światopoglądowego szkoły, jaki zaistniał po powtórnym wprowadzeniu religii do szkół w 1957 r. Po raz pierwszy prawo oświatowe objęło zasięgiem swojego oddziaływania nie tylko szkoły, ale także pozaszkolne placówki oświatowo-wychowawcze. W artykule 1 ustawy napisano:

Nauczanie i wychowanie w szkołach i innych placówkach oświatowo-wychowawczych ma na celu wszechstronny rozwój uczniów i wychowanie ich na świadomych i twórczych obywateli Polskiej Rzeczypospolitej Ludowej. [...]. Szkoły [...] wychowują w duchu socjalistycznej moralności i socjalistycznych zasad współżycia społecznego.

W artykule 2 stwierdzano natomiast: Szkoły i inne placówki oświatowowychowawcze sq instytucjami świeckimi. Catoksztatt nauczania i wychowania w tych instytucjach ma charakter świecki ${ }^{51}$.

Stanowisko T. Mazowieckiego wobec reformy oświaty zaprezentowane z mównicy sejmowej w imieniu środowiska Znaku rozwijane było na łamach

${ }^{50}$ Ibidem, ł. 89-90.

51 Ustawa z dnia 15 lipca 1961 r., DzU 1961, nr 32, poz. 160. 
"Więzi”. J. Wejroch i A. Wielowieyski informowali, że Polska u progu lat 60. stanęła wobec kryzysu sprawności systemu edukacji ${ }^{52}$. Publicyści wskazywali, że znalazła się ona w sytuacji, w której traciła dystans do najbliższych sąsiadów, którzy skuteczniej przystąpili do reform oświatowych. Przytaczali oni również dane z opracowań PAN-u, z dyskusji na VII Plenum, z wypowiedzi Ministra Oświaty, z artykułów zamieszczanych na łamach „Przeglądu Kulturalnego”, „Nowych Dróg”, „Życia Gospodarczego”, z których wyłaniał się groźny, bo pozostający w tyle za potrzebami życia społecznego, wizerunek szkolnictwa ${ }^{53}$. Stefan Kunowski, włączając się do dyskusji prowadzonej na szpaltach „Więzi” wywołanej przyjęciem ustawy o rozwoju systemu oświaty i wychowania, formułował pytania: czy zamierzone plany nauczania doprowadzą do osiągnięcia wyznaczonych uprzednio celów kształcenia i wychowania, czy są one lepsze od dotychczasowych oraz jaką mają szansę skutecznej realizacji ?4 $^{54}$

U progu rozpoczynającej się debaty publicyści warszawskiego miesięcznika zwracali uwagę, że zakres reform systemu oświaty warunkowany był w większym stopniu przez wymogi gospodarki niż przez ideały demokratyczne czy wzorce kulturowe ${ }^{55}$. Dotychczasowy jego rozwój bowiem, pomimo postępu, pozostawał w tyle za głównymi sferami przeobrażeń społeczno-gospodarczych kraju. Kryzys oświaty w ich przekonaniu polegał nie tylko na braku możliwości szybkiego nadrabiania opóźnień, lecz przede wszystkim na niedostosowaniu systemu szkolnego do rozwijającej się struktury społeczno-gospodarczej. Pogłębiająca się dysproporcja pomiędzy rozwojem czynników materialno-technicznych a rozwojem ludzkiego czynnika kwalifikacji ściśle związanego z rozwojem kultury społecznej ich zdaniem mogła stać się poważnym zagrożeniem dla harmonijnego rozwoju życia społecznego.

Z przytaczanych na łamach „Więzi” danych wynikało, że wprawdzie od czasu wojny nastąpił znaczny rozwój szkolnictwa zwłaszcza zawodowego (które w roku szkolnym 1960/1961 objęło dwa i pół raza więcej uczniów niż w roku 1946/1947), ale był on dużo niższy od rozwoju całej gospodarki i od zapotrzebowania na wykwalifikowane kadry ${ }^{56}$. Publicyści informowa-

52 J. Wejroch, A. Wielowieyski, op. cit., s. 5-20.

53 Ibidem, s. 8.

54 S. Kunowski, Głosy na marginesie projektu reformy szkolnictwa, „Więź”, 1962, nr 7, s. 8-9.

55 J. Wejroch, A. Wielowieyski, op. cit., s. 8.

56 Ibidem, s. 8-9. 
li, że dla lat 1961-1965 przewidywano ostry niedobór we wszystkich zasadniczych grupach pracowników wykwalifikowanych. Z tytułu samego tylko wzrostu potrzeb gospodarki występowało zapotrzebowanie na około 200 tys. nowych pracowników z wykształceniem wyższym, z czego uczelnie mogły pokryć zapotrzebowanie tylko w około 50\%. Zapotrzebowanie na kadry ze średnim wykształceniem technicznym szacowano na 400 tys., technika i licea zawodowe wykształcić mogły tylko około 300 tys. W zakresie kadr robotników wykwalifikowanych na 600 tys. potrzebnych pracowników szkoły zawodowe mogły dostarczyć jedynie około 400 tys. W tym kontekście z przytoczonych obliczeń wynikało, że w nadchodzącej pięciolatce zabraknie około 26 tys. inżynierów, 25 tys. ekonomistów, a brakujące 200 tys. pracowników zostanie jedynie przyuczone do zawodu w zakładach pracy.

Równie ważnym problemem akcentowanym na łamach warszawskiego miesięcznika był utrzymujący się zwłaszcza na wsi wysoki odsetek (22-25\%) uczniów niekończących szkoły podstawowej ${ }^{57}$. Młodzież ta w ocenie publicystów prawdopodobnie zostanie objęta systemem szkolnictwa przysposobienia zawodowego, w wyniku którego otrzyma jedynie, niedającą systematycznego i dostatecznego przygotowania do zawodu, namiastkę wykształcenia zawodowego. Według przytaczanych danych jeszcze w 1965 r. prawie milion młodzieży nie zostanie objęty niższą lub pełną szkołą średnią ${ }^{58}$. W konkluzji A. Wejroch i A. Wielowieyski stwierdzali, że w Polsce w dalszym ciągu nie było warunków i środków dla zapewnienia powszechności pełnej szkoły podstawowej, nie mówiąc o upowszechnieniu zasadniczego szkolnictwa zawodowego, podczas gdy współczesna technika i organizacja pracy wymagały powszechności wykształcenia na poziomie średnim. Plany polityki oświatowej zakładały bowiem możliwość zapewnienia dziesięcioletniego cyklu nauki w szkole dopiero za 8-10 lat.

Kryzys sytemu oświatowego w opinii autorów wyrażał się nie tylko w ilościowej niewydolności szkolnictwa, ale wiązał się ściśle z pięcioma sprzecznościami występującymi w systemie kształcenia, wychowania oraz w organizacji pracy szkoły ${ }^{59}$. Pierwszą z nich była rozbieżność pomiędzy postulatem powszechności oświaty i równości społecznej a wymogami gospodarki i organizacji życia społecznego. Zapewnienie jednolitej i powszechnej

57 J. Wejroch, A. Wielowieyski, Kryzys i reforma systemu oświaty (II), „Więż”, 1962, nr 6, s. 102 .

58 Iidem, Kryzys i reforma systemu oświaty, s. 9.

59 Ibidem, s. 11-16. 
szkoły średniej wymagało olbrzymiego skoku inwestycyjnego i organizacyjnego oraz czasu, którego nie było z uwagi na bieżące ogromne zapotrzebowanie na wykwalifikowane kadry. Implikowało to elitarne formy kształcenia oraz ostrą selekcję, a w konsekwencji prowadziło do systematycznego zmniejszania się odsetka młodzieży chłopskiej i robotniczej w szkołach średnich ogólnokształcących i na wyższych uczelniach ${ }^{60}$. Spostrzeżenia te pozostawały w ścisłym związku z drugą sprzecznością polegającą na przeciwstawianiu wykształcenia ogólnego wykształceniu specjalistycznemu. Publicyści „Więzi” w dyskusjach, w których strony opowiadały się za jednym lub drugim modelem kształcenia, dowodzili, że konflikt racji był pozorny, gdyż w tym przypadku obydwa kierunki myślenia o edukacji powinny się uzupełniać. Wskazując na konieczność ciągłego modernizowania treści i form nauczania podkreślali, że

szkoła średnia wszelkich typów powinna wychowywać człowieka z mocnymi podstawami kultury osobistej i społecznej, rozwiniętą inteligencją i teoretycznymi podstawami wiedzy ścisłej. W warunkach, gdy rosnąć będzie w społeczeństwie znaczenie różnego rodzaju specjalistów, tylko poziom powszechnej kultury ogólnej może być gwarancją demokracji. [...] Wiedza i kultura ogólna są niezbędne do aktywności zawodowej i pogłębienia szczegółowej specjalizacji. Sprostanie postępom wiedzy i techniki, zmieniającym się procesom technologicznym, wymaga bowiem coraz bardziej gruntownej wiedzy ogólnej i rozwiniętej inteligencji ${ }^{61}$.

Dwie powyższe sprzeczności w ich przekonaniu mogły zostać rozwiązane dopiero w dłuższej perspektywie czasowej, stworzenie młodzieży równych warunków kształcenia zależeć będzie bowiem od wyrównania poziomu kulturalnego całego społeczeństwa i od odpowiednich nakładów finansowych. Tylko 12-13-letnia zróżnicowana, ale jednolita szkoła podstawowa dla wszystkich w ich ocenie mogła stworzyć warunki dla pogodzenia wykształcenia ogólnego i specjalistycznego oraz zachowania wymogów niezbędnych do przygotowania fachowej elity o wysokich kwalifikacjach zawodowych.

Trzecia niekonsekwencja polegała na sprzeczności pomiędzy rosnącymi wymaganiami w zakresie ilości wiedzy i kwalifikacji a normami sfery higieny

${ }^{60}$ Szerzej zob.: J. Wiśniewski, Wychowanie merytokracji, „Więź”, 1961, nr 11-12, s. $82-88$.

${ }^{61} \mathrm{~J}$. Wejroch, A. Wielowieyski, Kryzys i reforma systemu oświaty, s. 13. 
psychicznej i fizycznej ucznia. Problemy te rozwiązać można było zdaniem zespołu "Więzi” jedynie poprzez radykalną przebudowę wewnętrzną szkoły, polegającą na zmianie jej organizacji oraz unowocześnienia metod kształcenia. Dowodzili, że utrzymanie tradycyjnego systemu klasowo-lekcyjnego, z nieznacznie tylko skorygowanymi programami nauczania i coraz większymi zadaniami, hamować będzie rozwój młodzieży oraz pogłębiać kryzys wydolności oświaty. Opowiadali się za uwspółcześnieniem szkoły polegającym na wprowadzeniu nowoczesnych środków przekazu kultury masowej oraz usamodzielnieniem pracy ucznia. Pożądane zaś zmiany w metodyce nauczania wymagały bowiem wyposażenia pracowni, ale przede wszystkim zmiany mentalności, postaw i kwalifikacji polskiego nauczyciela. W tym publicyści widzieli czwartą sprzeczność, polegającą na rozbieżności między postawą a kwalifikacjami znacznej części kadry pedagogicznej. Przełamanie bierności w tej grupie zawodowej, która powinna stanąć na czele ruchu reformy, uznano za zadanie o naczelnym charakterze. Wreszcie piątą była rozbieżność pomiędzy subiektywnymi postawami i poglądami Polaków na sprawy oświaty i wychowania a zadaniami, jakie przed systemem edukacji stawiały obiektywne potrzeby rozwoju społecznego. System nie będzie działał sprawnie, jeśli nie będzie miał zrozumienia dla swoich celów i metod pracy, tak wśród nauczycieli i rodziców, jaki i całego społeczeństwa. Analiza pięciu powyższych sprzeczności zdaniem publicystów wskazywała, że nie w problemie środków materialnych, a w poprawie klimatu i zaangażowaniu całego społeczeństwa w sprawy oświaty, w ożywieniu kadry nauczycielskiej i radykalnej zmianie metod nauczania, w koordynacji działań władz oświatowych i gospodarczych koncentrowały się największe trudności, a zarazem najpoważniejsze szanse na przyspieszenie dzieła reformy.

$\mathrm{Z}$ powodu braku możliwości upowszechnienia w latach 60. pełnego wykształcenia na poziomie średnim dyskusję na łamach „Więzi” na temat przekształceń oświatowych zdominowały problemy szkoły 8-letniej, jedynego ogniwa wykształcenia podstawowego, w którym zrealizowany miał być zasadniczy dla nowoczesnej szkoły postulat jednolitości. W przewidywaniach redakcji, ta co najmniej dziesięcioletnia zwłoka we wprowadzeniu pełnej reformy stanowić miała w przyszłości poważne obciążenie rozwoju społecznego $^{62}$. Postulowano zatem, by fakt wydłużenia o jeden rok okresu nauczania wykorzystać na podniesienie sprawności promocyjnej szkoły podstawowej

62 Iidem, Kryzys i reforma systemu oświaty (II), s. 101-112. 
poprzez napisanie nowych programów nauczania, które uwzględniałyby dotychczasowe trudności młodzieży ${ }^{63}$. Zamiast rozbudowywania programów proponowano skupić uwagę na lepszym i bardziej efektywnym rozłożeniu treści nauczania w czasie całego cyklu kształcenia. Zabieg ten pozwoliłby skuteczniej egzekwować ustawowy obowiązek i prawo powszechności nauczania w zakresie pełnej szkoły podstawowej.

Na łamach „Więzi” przytaczano również opinie ekspertów Mariana Falskiego i Stefana Kunowskiego, które wskazywały na niepokojące ubóstwo wypowiedzi określających cele reformy, jak i metody ich realizacji. M. Falski stwierdzał, że perspektywiczne cele szkoły zostały sformułowane ogólnikowo i niejasno, bez wyraźnego powiązania ich z potrzebami współczesnego życia oraz bez zajęcia stanowiska w stosunku do przestarzałych XIX-wiecznych teorii i metod nauczania ${ }^{64}$. Koncepcja 8-latki w ocenie M. Falskiego czyniła wrażenie kompromisu pomiędzy dotychczasową szkołą i jej metodami nauczania a pewnymi postulatami projektów reformy przedstawionymi przez B. Suchodolskiego ${ }^{65}$. Poglądy te podziałał Stefan Kunowski ${ }^{66}$. W jego opinii ogólny charakter projektów reformy był wyrazem kompromisu między rewolucyjną zmianą, jaką zawierał projekt B. Suchodolskiego, a dotychczasowym stadium przemian programowych ${ }^{67}$. Zasadniczy spór pomiędzy radykalnym programem zmian a obecnie obowiązującym jeszcze programem nauczania dotyczył dwóch modeli wychowania tzw. wychowania uczestniczącego i wychowania przygotowującego ${ }^{68}$.

Wiele kontrowersji wzbudzała także zmiana profilu dydaktycznego reformowanych szkół ${ }^{69}$. Projekty ministerialne zmierzały bowiem w kierunku poszerzania zakresu wymaganych wiadomości z niektórych przedmiotów nauczania oraz zmniejszania równocześnie liczby godzin przedmiotów humanistycznych. Profil dydaktyczny 8-letniej szkoły podstawowej miał zmienić się w kierunku

63 Ibidem, s. 102-103.

${ }^{64}$ Ibidem, s. 105.

${ }_{65}$ Zob.: B. Suchodolski, O nowoczesna koncepcje 8-letnie szkoły podstawowej, „Głos Nauczycielski” 1961, nr 10,12, 14, 15, 17, 20, 21, 23, 27, 32,43, 45.

66 S. Kunowski, op. cit., s. 90.

${ }^{67}$ Ibidem, s. 90-91.

68 Wychowanie uczestniczące kładło nacisk na empiryczne zetknięcie ucznia z życiem społecznym i dziedzinami kultury, natomiast przygotowujące działało odwrotnie, zaczynało się od podawania gotowych wiadomości, od formowania pojęć i postaw ucznia, zanim przystąpi on do praktycznego ich zastosowania.

69 S. Kunowski, op. cit., s. 95. 
poszerzenia przedmiotów techniczno-estetycznych oraz wybranych przedmiotów humanistyczno-społecznych. Podobne przegrupowania przygotowywano dla liceum ogólnokształcącego ${ }^{70}$. Przedłożony projekt planu nauczania 8-klasowej szkoły podstawowej stanowił próbę pogodzenia dotychczasowych kilku tradycyjnych przedmiotów nauczania z nowo wprowadzonymi kierunkami wychowania uczestniczącego, wychowania społecznego, wychowania plastycznego, wychowania muzycznego, czy wychowania fizycznego.

Krytycznie o likwidacji godziny wychowawczej i zastąpieniu jej wychowaniem społecznym, w ramach którego nauczanie miało objąć problemy etyczne, socjologiczne aspekty nauki obywatelskiej i ustrojowej państwa, a równocześnie przygotować uczniów do życia społecznego i politycznego poprzez wykonywanie prac społecznie użytecznych przez zespół klasowy wypowiadał się S. Kunowski. Takie połączenie wychowania uczestniczącego w życiu społeczeństwa z nauczaniem zasad moralności socjalistycznej, podstaw prawnych ustroju i zjawisk życia politycznego w Polsce i świecie, teoretycznie uzasadnione, w praktyce szkolnej zdaniem S. Kunowskiego mogło okazać się trudne do realizacji na skutek niedojrzałości umysłowej i społecznej uczniów, a także ich niezdolności do syntezy oraz do zainteresowania się sprawami przewyższającymi możliwości percepcji w wieku dorastania. Sformułował on tezę, że na poziomie szkoły podstawowej niemożliwa jest realizacja celów z zakresu formowania światopoglądu ideowego ucznia oraz kształcenia jego kwalifikacji zawodowych ${ }^{71}$. Krytycznie wyrażał się także o braku w programie szkoły podstawowej lekcji z wychowania seksualnego według wzorów szwedzkich czy szkockich ${ }^{72}$. W jego przekonaniu pozostawienie tego problemu w gestii nauczyciela biologii było nieporozumieniem. Warto w tym miejscu zauważyć, iż, rozumiejąc wagę problemów wychowania seksualnego, redakcja „Więzi”, wychodząc naprzeciw zapotrzebowaniu uczniów i ich rodziców, opublikowała na swych łamach cykl artykułów poświęconych tym zagadnieniom, których nie uwzględniano w programach szkolnych ${ }^{73}$.

70 Zajęcia w liceum ogólnokształcącym z przedmiotów techniczno-estetycznych z 21 godzin w ciągu 4 lat nauki miałyby wzrosnąć do 33 godzin, co stanowiło 1/4 całego programu nauczania. Równocześnie planowano poszerzyć liczbę godzin na korzyść grupy matematyczno-przyrodniczej ze szkodą dla kształcenia humanistyczno-społecznego, w celu zbliżenia szkoły do współczesności, do postępu w nauce, technice i sztuce; zob.: S. Kunowski, op. cit., s. 95.

71 Ibidem, s. 96.

72 Ibidem, s. 97.

73 Cały numer poświęcony zagadnieniom życia seksualnego, zob.: „Więź”, 1962, nr 8. Problematyce małżeństwa i życia seksualnego poświecono już wcześniej na łamach warszaw- 
Analizując nowy program szkoły 8-letniej, m.in. pod kątem rozszerzenia oraz uwspółcześnienia treści kształcenia, zwłaszcza w zakresie przedmiotów matematyczno-przyrodniczych oraz postulatu wprowadzenia politechnizacji nauczania, J. Wejroch i A. Wielowieyski zgłaszali wiele zastrzeżeń i wątpliwości. Pytali: czy wzrost wymagań programowych nie wpłynie na promocję uczniów, czy w obecnych warunkach w polskim systemie nauczania możliwe jest szerokie zastosowanie metod uczestnictwa? Wskazywali, że w koncepcji politechnizacji brak jest odniesienia do potrzeb społecznych, poza słusznym postulatem nauczania pewnych umiejętności praktycznych nie dostrzegli jasno sprecyzowanych zaleceń merytoryczno-dydaktycznych. Zauważali, że fetyszyzacja upraktyczniania procesu nauczania bez jasnego sprecyzowania funkcji wychowawczych szkoły oraz bez konkretnych celów bieżących (życiowych) może okazać się pomysłem chybionym w dłuższej perspektywie edukacyjnej. Rozważania powyższe doprowadziły ich do postawienia pytania: jakiej kulturze technicznej ma służyć politechnizacja? Podkreślali, że

nowoczesna kultura techniczna to [...] w coraz mniejszym stopniu kształcenie sprawności manualnych, posługiwania się prostymi narzędziami i bezpośredniego obcowania z zewnętrznymi cechami tworzywa. Nowoczesna kultura techniczna - to przede wszystkim sprawność inteligencji, oparta o ogólną wiedzę ścisłą, umiejętność koncentracji uwagi, szybkość reakcji wyostrzonych zmysłów, organizacja i umiejętność sprawnego i harmonijnego współdziałania z innymi ludźmi. Wszystkie te czynniki składowe współczesnej kultury technicznej mają swoją podstawę w dobrym przygotowaniu ogólnym człowieka, w poziomie jego wiedzy i kultury społecznej ${ }^{74}$.

Sformułowane w projekcie szkoły 8-letniej podejście do zagadnienia politechnizacji spowodować mogło w ich ocenie napływ do szkół zawodowych gorzej przygotowanych kandydatów na przeszłych specjalistów z wykształceniem średnim. W konsekwencji byli oni przeciwni zaproponowanemu przez władze oświatowe modelowi politechnizacji szkół, opowiadali

skiego miesięcznika wiele uwagi, zob.: A. Olędzka-Frybesowa, Kryzys i szanse wspótczesnej rodziny, „Więź”, 1959, nr 12, s. 13-28; I. Ryżewska, Autorytet męża i żony-wczoraj i dziś, „Więź”, 1960, nr 6, s. 111-121; J. Massalaska, Więcej światta w sprawach „wstydliwych” (uwagi o zagadnieniach doboru seksualnego), „Więź”, 1961, nr 11-12, s. 156-166; F. Heer, Przeobrażenia rodziny, „Więź”, 1962, nr 3, s. 5-24, i in.

${ }_{74}$ J. Wejroch, A. Wielowieyski, Kryzys i reforma systemu oświaty (II), s. 106. 
się za utrzymaniem tradycyjnych elementów programu nauczania zakresie kształcenia kultury technicznej młodzieży.

Publicyści warszawskiego miesięcznika odważne formułowali tezę, że w miejsce politechnizacji należałoby wprowadzić elementy socjotechnizacji szkoły. Politechnizacji na poziome nowoczesnym, rozumianej jako proces wyrobienia umiejętności techniczno-sprawnościowych, w ich przekonaniu nie da się wprowadzić do szkoły. Tym samym nabywanie umiejętności technicznych nie powinno być celem samym w sobie. Należało kłaść nacisk nie na zręczność manualną, która łatwo przechodzi w automatyczną wprawę, lecz na umysłową stronę pracy ręcznej, na sens wysiłku konstrukcyjnego. Celem wychowania technicznego winno być nie tyle wyrabianie poszczególnych sprawności, ile rozbudowa wyobraźni technicznej i społecznej, uczenie rozumienia całokształtu wytwórczości i społecznej organizacji pracy.

W dyskusji dotyczącej zmian programowych liceum ogólnokształcącemu poświecono znacznie mniej uwagi. Swoistą ciekawość wzbudził fakt, że przygotowana propozycja programowa dla szkół licealnych stwarzała de facto dwie możliwości realizacji perspektywicznych celów szkoły ${ }^{75}$. Nadrzędne ustawowe zadania o brzmieniu: zapewnić wyksztatcenie ogólne i politechniczne, niezbędne do podjęcia studiów wyższych oraz przysposobienie do pracy zawodowej, proponowano realizować według dwóch możliwych do wyboru wariantów. W wersji maksymalnej do zadań liceum ogólnokształcącego należało a) wykształcenie ogólne młodzieży w zakresie nauk społecznych i matematyczno-przyrodniczych, będących podstawą naukowego poglądu na świat, b) wdrażanie do samodzielnego myślenia i samokształcenia, c) wyrabianie umiejętności stosowania nabytej wiedzy w praktyce. W wersji minimalnej, zapisanej w konkluzji projektu programu licealnego, do zadań szkoły zaliczono: a) lepsze przygotowanie do studiów wyższych przez powiększenie zakresu wiedzy i zróżnicowanie programu na dwa typy humanistycznego i matematyczno-przyrodniczego liceum, b) zbliżenie szkoły ogólnokształcącej do zawodowej przez kształcenie politechniczne i przysposobienie zawodowe, c) uwspółcześnienie treści nauczania przedmiotów oraz metod samodzielnej pracy, d) nasilenie elementów wychowania społecznego.

Do projektu programu licealnego zgłoszono wiele wątpliwości, stawiając pytania: czy zaplanowane zamierzenia nie pozostaną jedynie dekla-

75 S. Kunowski, op. cit., s. 100. 
racją dobrych intencji; czy do nauk społecznych zalicza się wszystkie nauki humanistyczne, czy tylko naukę obywatelską i historię ujmowaną głównie od strony walki klasowej i rozwoju produkcji. Wyrażano nadzieję, że podstawa naukowego poglądu na świat będzie się poszerzać i owa elastyczność znajdzie odzwierciedlenie również w programie liceum ogólnokształcącego. Zwracano uwagę, że cenne byłoby przyjęcie zasady samodzielności myślenia ucznia, lecz brak w projekcie propedeutyki filozofii i logiki, które dotąd były uwzględniane programie w liceum, osłabi i utrudni wyrobienie krytycyzmu i samodzielności intelektualnej. Zaniepokojenie wzbudzał również fakt, że w przedłożonym projekcie nauki społeczne koncentrowały się tylko na "nauce o społeczeństwie i wiadomościach o Polsce i świecie współczesnym" (powiększonej o 4 godziny w ciągu dwóch lat). Zastrzeżenia budziło również stwierdzenie, że nadrzędnym celem tych zajęć miało być wychowanie społeczno-polityczne, którego wartością nadrzędną było nie tyle przekazywanie wiedzy, ile rozwijanie aktywności społecznej młodzieży i wdrażanie jej do postępowania zgodnie z zasadami moralności socjalistycznej. Nie podzielano optymizmu twórców reformy, że pomocny w tym zakresie okaże się model kształcenia politechnicznego z 16-godzinnym blokiem zajęć technicznych.

Całościowa ocena projektów programu nauczania dla szkoły podstawowej i liceum ogólnokształcącego dokonana na łamach „Więzi” przez publicystów miesięcznika, jak i wypowiadających się specjalistów była krytyczna. W ogólnej konkluzji S. Kunowski wskazywał, że analizowany projekt programu dla szkoły podstawowej podejmował nazbyt dużą liczbę zadań, spośród których wiele w tym okresie rozwojowym było niemożliwych do realizacji. Na skutek dostrzeganych rozbieżności pomiędzy zamiarami a możliwościami wykonania wskazywał on na wrażenie fasadowości czy deklaratywności dokumentu prawa oświatowego, który porównał do weksla bez pokrycia $^{76}$.

Interpretując z kolei propozycje programowe dla liceum ogólnokształcącego oraz możliwość realizacji zadań ustawowych w dwóch wersjach osiągania celów: minimalnej i maksymalnej, S. Kunowski oceniał je jako akt braku wiary władz oświatowych w możliwość realizacji sformułowanych celów kształcenia i wychowania ${ }^{77}$. Jeśli wersję minimalną potraktować jako mini-

\footnotetext{
76 Ibidem, s. 97.

77 Ibidem, s. 99-100.
} 
mum możliwe do osiągnięcia, to jego zdaniem maksimum należało rozumieć w kategoriach eksperymentu, który nie musiał zakończyć się powodzeniem. W płaszczyźnie maksymalnej rozwinięta koncepcja programowa dla liceum ogólnokształcącego w jego ocenie była nierealna, wykraczała bowiem daleko poza cel wymieniony w ustawie. Projekt programu licealnego zakładał nazbyt optymistycznie osiągniecie maksymalnych celów wychowania socjalistycznego na poziomie szkoły średniej, nie pozostawiając nic do wykonania z tego zakresu szkołom wyższym, chociaż one też miały nałożone obowiązki w sferze wychowania socjalistycznej inteligencji.

Publicyści, analizując problem perspektywicznie, zauważali, że przedłużenie nauczania w szkole podstawowej do 8 lat, skorygowanie programu ogólnokształcącej szkoły średniej oraz podwojenie do roku 1965 liczby absolwentów szkolnictwa zawodowego, stanowiące trzon realizowanej reformy - to tylko „mała reforma”78. Zwracali uwagę, że resort oświaty niezwykle ostrożnie podchodził do dyskusji o „wielkiej reformie” oraz do zbudowania w tym celu pomostu ze światem nauki. W tym kontekście przypomnieli oni wypowiedź Mikołaja Kozakiewicza, który w nr 3 „Kwartalnika Pedagogicznego" z 1961 r. wypominał Ministerstwu Oświaty, że jako jedyne ze wszystkich resortów gospodarczych nie posiadało zaplecza naukowego. Dyskusja nad „małą reformą” i nowymi programami toczyła się ospale, gdyż w praktyce trzech tylko ludzi, M. Falski, B. Suchodolski i M. Kozakiewicz, podejmowało publicznie sprawy reformy, a to było w ocenie redakcji, jak na trzydziestomilionowy naród, o wiele za mało. Reforma winna być permanentna, bez tego szkoła nie dorówna do przemian społecznych w kraju, nie wytrzyma tempa, które jej narzucono. J. Wejroch i A. Wielowieyski stwierdzali, że już dzisiaj powinniśmy mieć nakreślone kolejne etapy jej realizacji, proponowali również, aby hasło „1000 szkół na 1000-lecie” uzupełnić ideą „Każda szkoła polska aktywnym ogniwem reformy nauczania i wychowania"79.

W nowej rzeczywistości politycznej po kryzysie z grudnia 1970 r., kiedy rozpoczęła się kolejna debata na temat systemu oświaty, J. Wejroch konsekwentnie zajmujący się na łamach „Więzi” sprawami edukacji tak oceniał sytuację:

78 J. Wejroch, A. Wielowieyski, Kryzys i reforma systemu oświaty, s. 17-18.

79 Ibidem, s. 20. 
Nie jest tajemnicą, że przy względnie znacznych osiągnięciach w rozwoju systemu szkolnego w ciągu ostatnich dwudziestu pięciu lat pozostajemy jednak w tyle za wieloma krajami, w tym za naszymi sąsiadami, [...] ZSRR i NRD ${ }^{80}$.

\section{W imieniu środowiska stwierdzał:}

najwyższy czas już chyba, żeby odważnie spojrzeć w oczy wymogom rzeczywistości i rozpocząć proces gruntownej przebudowy podstaw i założeń systemu szkolnego równolegle do zmian strukturalnych, modelowych i organizacyjnych w granicach istniejącego systemu ${ }^{81}$.

Debata na temat oświaty powróciła na szpalty „Więzi”82. W sprawie konieczności wprowadzenia odważnych zmian w edukacji wypowiedziało się Kolegium Redakcyjne, głos zabrał również Tadeusz Mazowiecki. Zespół redagujący warszawski miesięcznik w artykule Po wydarzeniach grudnia, genezy kryzysu polityczno-społecznego doszukiwał się między innymi w nierozwiązanych problemach systemu oświaty i wychowania. Oceniając efekty działań instytucji oświatowo-wychowawczych pisano wówczas:

praca instytucji nauki, oświaty i propagandy [...] nie stanęła na poziomie, który by odpowiadał powadze sytuacji. Luka pomiędzy rzeczywistością a ukazywanym jej obrazem była zbyt wielka. Zjawiska te stały się brzemienne w skutki w wielu dziedzinach ${ }^{83}$.

Redaktor naczelny w artykule o rozliczeniowym charakterze po odniesieniu się w pierwszej kolejności do problemów gospodarczych wskazał na konieczność pilnych i zasadniczych zmian całego systemu oświaty i wychowania $^{84}$. Pytał:

${ }^{80}$ J. Wejroch, O szkotę dla jutra, „Więź”, 1971, nr 4, s. 3.

81 Ibidem, s. 10.

82 Dyskusja o reformie systemu oświaty i wychowania, „Więź”, 1972, nr 6, s. 3-18; Nad „Raportem o stanie oświaty”. W perspektywie potrzeb społecznych, „Więż”, 1973, nr 10, s. 32-55; A. Grzegorczyk, Kultura logiczna a zadania szkoty, „Więż”, 1974, nr 2, s. 74-83.

83 Kolegium Redakcyjne, Po wydarzeniach grudnia 1970, „Więź”, 1971, nr 1, s. 3.

84 T. Mazowiecki, Szansa, „Więź”, 1971, nr 11, s. 6-7. 
Czy można ten proces [reform] przeprowadzić bez gruntownej zmiany wielu nastawień oddziałujących niejednokrotnie deformująco na cały nasz układ oświatowy i wychowawczy? Powodzenie prawdziwie nam niezbędnej reformy zależeć będzie już nie od krótkosezonowych eksperymentów w rodzaju politechnizacji, prymitywnie pojętej i realizowanej, lecz od spojrzenia fundamentalnego na rolę szkoły, ma jej możliwości i zadania we współczesnym społeczeństwie. Nazywaliśmy to w naszej publicystyce socjalizacyjną rolą szkoły, rozumiejąc przez to konieczność przystosowania dzieci i młodzieży przez szkołę do współczesnego społeczeństwa [...] Już dziś widać też, że wobec tempa zmian w technice i nauce na plan pierwszy w sposobach kształcenia wysuwać się dostarczenie możliwie dobrego wykształcenia ogólnego, dającego podstawy wyjściowe do kontynuacji wykształcenia i specjalizacji. Wszystko to wymagać będzie gruntownej i wszechstronnej dyskusji, gdy opublikowany zastanie raport oświatowej komisji ekspertów. Żadna jednak ustawa ani tym bardziej ministerialny okólnik nie przetworzą najmądrzejszych sugestii raportu oświatowego w rzeczywistość. Tym bardziej, że stawiamy sobie zarazem ambitne zadania upowszechnienia, w stosunkowo krótkim czasie, wykształcenia na poziomie średnim ${ }^{85}$.

Rzeczywistość lat kolejnych pokazała, że władze oświatowe, przygotowując kolejną reformę, uchwaloną przez sejm w dwusetną rocznicę utworzenia Komisji Edukacji Narodowej 13 października 1973 r., nie zaakceptowały żadnego z proponowanych wariantów przekształceń systemowych zaproponowanych przez Komitet Ekspertów w „Raporcie o stanie oświaty w PRL" $"$.

85 Ibidem, s. 6.

${ }^{86}$ M. Strzelecka, op. cit., s. 222-229; Raport o stanie oświaty w PRL, Warszawa 1973; K. Trzebiatowski, J. Żerko, System oświatowy na tle porównawczym, Gdańsk 1990, s. 48-106. 


\section{'Więz' journal community towards the reforms of the educational system in 1950s and 1960s \\ Summary}

The group of columnists gathered around 'Więż' journal fostered the traditional Catholic values, encouraged participation in the Catholic community and promoted the idea of social commitment of Catholics. They acknowledged the fact of implementation of socialist reforms in Poland as inevitable. Apart from socio-cultural and historical issues, long-term intellectual work on shaping young Poles attitudes and behaviour was of interest to the 'Więź journal community. According to 'Więz' journal editors, it was education that ascribed the main role in the process of building a human society and social order. The interests of 'Więź journal community in the educational issues resulted from the above premises. 'Więź journal community willingly accepted the readiness of the Polish educational authorities for wide-ranging reforms in 1956/57 and 1961. The complex educational problems were repeatedly analysed in 'Więź journal. 